\title{
DOCTRINE OF TRINITY: A THEOLOGICAL APPROACH OF EVIDENCE OF THE TRINITY IN THE NEW TESTAMENT
}

\author{
Made Astika \\ sttjaffraymakassar@yahoo.co.id \\ astikadek@yahoo.com
}

\section{INTRODUCTION}

Jehovah's Witnesses saying, "The word trinity is not in the Bible" is therefore as irrelevant as it is illogical and quite meaningless. Jehovah's Witnesses are hypocrites for using the false argument that since the word Trinity is not found in the Bible, this must mean it is a false doctrine! $!^{1}$

The word "Trinity" is not found in Scripture, but is used to express the doctrine of the unity of God as subsisting in three distinct Persons. This word is derived from the Greek trias (a set of three) or from the Latin trinitas (an abstract Latin noun that most literally means three-ness). It was first used by Tertullian (A.D. 220), to refer to Father, Son and Holy Spirit. Trinity is used in general, for any set of three things. ${ }^{2}$

One of the main fundamental key truths in Christianity is the belief in the doctrine of the Trinity. The Trinity of God is a doctrine that is fundamental to the Christian faith; belief or disbelief in the Trinity marks or orthodoxy or from unorthodoxy. Human reason, however, cannot fathom the Trinity, nor can logic expalin it, and, although the word itself is not found in the Scriptures, the doctrine is plainly taugh in the Scriptures. The early church was forced to study the subject and affirm its truth because of the heretical teachings that arose opposing the Trinity.

The Trinity is the term employed to signify the central doctrine of the Christian religion. The truth, that in the unity of the Godhead there are Three Persons, the Father, the Son, and the Holy Spirit, these Three Persons being truly distinct one from another.

\footnotetext{
${ }^{1}$ Watchtower Hypocrisy: "The word Trinity is not found in the Bible?" Available from, http://www.bible.ca/trinity/trinity-word-not-in-bible.htm, accessed on September $14^{\text {th }}$ 2009.

${ }^{2}$ Carol Brooks, The Trinity, available from, http://www.inplainsite.org/html/the_trinity.html, accessed on September, $5^{\text {th }} 2009$.
} 
A proper definition of the Trinity states: "The Trinity is composed of three united persons without separate existence - so completely united as to form one God. The divine nature subsists in three distinctions - Father, Son, and Holy Spirit. ${ }^{3}$

Simply put, the doctrine of the Trinity states that there is: One God in three Persons. It is not three Gods in one God - it is one God in three Persons. The Bible specifically states over and over again that there is only one God. There are not three Gods in one God. God the Father is the first Person of the Trinity, His Son Jesus Christ is the second Person of the Trinity and the Holy Spirit is the third Person of the Trinity. Athanasius wrote in the Athanasian Creed: "the Father is God, the Son is God, and the Holy Spirit is God, and yet there are not three Gods but one God."

Thiessen explained that the doctrine of Trinity must be distinguished from both Tritheism and Sabellianism.

Tritheism denies the unity of the essence of God and holds to three distinct Gods. The only unity that it recognizes is the unity of purpose and endeavor ... Sabellianism held to a trinity revelation, but not of nature. It thought that God, as Father, is the creator and lawgiver; as Son, is the same God incarnate who fulfills the office of redeemer; and as Holy Spirit, is the same God in the work of regeneration and sanctification. In other words, Sabellianism taught a modal trinity as distinguished from an ontological trinity. Modalism speaks of a threefold nature of God, in the same sense in which a man may be an artist, a teacher, and a friend, or as one may be a father, a son, and a brother. ${ }^{5}$

So God is one, but somehow also three. This fact is difficult to understand, but it is quite unavoidable in Scripture and central of the gospel. The doctrine of the Trinity attempts to account for this fact and to exclude heresies that have arisen on the subject. Its basic assertions are these: (1) God is one. (2) God is three. (3) The three persons are each

\footnotetext{
${ }^{3}$ Paul Enns, The Moody Handbook of Theology, (Chicago: Moody Press, 1989), 199.

${ }^{4}$ Kevin Knight ed., The Blessed Trinity, available from, http://www.newadvent.org/cathen/15047a.htm, accessed on September $5^{\text {th }} 2009$.

${ }^{5}$ Henry Clarence Thiessen, Lecture in Systematic Theology (Grand Rapids, Michigan: William B. Eerdmans Publishing Company, 1987), 90.
} 
fully God. (4) Each of the persons is distinct from the others. (5) The three persons are related to one another eternally as Father, Son, and Holy Spirit. $^{6}$

In God there are no three individuals alongside of, and separate from one another, but only personal self-distinctions within the Divine essence. ${ }^{7}$ God as the Father Almighty, who is the source of life, who makes Himself known in Jesus Christ by the power of the Spirit of God who is present throughout the historical process, working to transform it according to God's purpose. ${ }^{8}$

Below is the best symbol for the Trinity, ${ }^{9}$ the Ancient Diagram of the Holy Trinity. ${ }^{10}$

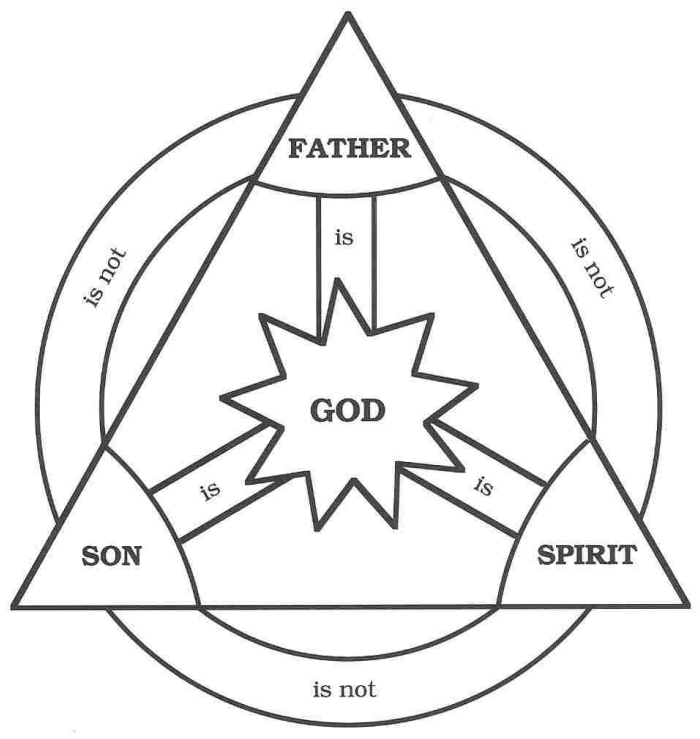

${ }^{6}$ John M. Frame, The Doctrine of God (Phillipsburg, New Jersey: P\&\&R Publishing Company, 2002), 621.

${ }^{7}$ Louis Berkhof, Systematic Theology (Grand Rapids: William B Eerdmans, 1941), 87.

${ }^{8}$ Thomas C. Oden, The Living God (New York: Harper Collins Publisher, 1987), 181.

${ }^{9}$ The symbol for the Trinity, available from, http://www.gotquestions.org/TrinityBible.html, accessed on September, $14^{\text {th }} 2009$. 201.

${ }^{10}$ Paul Enns, The Moody Handbook of Theology, (Chicago: Moody Press, 1989), 


\section{Chapter I \\ HISTORY OF THE DOCTRINE OF TRINITY}

The orthodox doctrine of the Trinity was enunciated in a series of debates and councils which were in large part prompted by the controversies sparked by such movements as monarchianism and Arianism. ${ }^{11}$

The doctrine of the trinity, as defined by the Nicene Creed (AD 325) confirmed by the Council of Constantinople (AD 381) and amplified somewhat by the Council of Chalcedon (AD 45l) is that the Father, the Son and the Holy Spirit are of the same substance (Greek homoiousis). ${ }^{12}$

Though the term "Trinity" does not occur in the Bible, it had very early in the church. Perhaps the best question we can ask is whether this doctrine, as defined by the Orthodox Christian Church in the third through fifth centuries is indeed true and biblical.

The word trias (of which the Latin trinitas is a translation) is first found in Theophilus of Antioch about A.D. 180. He speaks of "the Trinity of God [the Father], His Word and His Wisdom (To Autolycus II.15). The term may, of course, have been in use before his time. Afterwards it appears in its Latin form of trinitas in Tertullian (On Pudicity 21). In the next century the word is in general use. It is found in many passages of Origen ("In Ps. xvii", 15). ${ }^{13}$

The writers of this school contend that the doctrine of the Trinity, as professed by the Church, is not contained in the New Testament, but that it was first formulated in the second century and received final approbation in the fourth, as the result of the Arian and Macedonian controversies.

The development of the doctrine of the Trinity happened in stages, over a period of at least a couple of hundred years. From the time of Justin Martyr in the second century, post-New Testament writers wrestled with the central Christian mystery of the tripersonal God. How

\footnotetext{
${ }^{11}$ Millard J. Erickson, Christian Theology (Grand Rapids, Michigan: Baker Book House, 1996), 335.

${ }^{12}$ John Oakes, The Origin of the Trinity, available from, http://www.evidenceforchristianity.org/ index.php?option=com_custom_content\&etask=view\& $\&$ id $=4999$, cited on September $14^{\text {th }}$ 2009.

${ }^{13}$ Kevin Knight ed., The Blessed Trinity, available from, http://www.newadvent.org/cathen/15047a.htm, accessed on September $5^{\text {th }} 2009$.
} 
could they grasp, even marginally, the differentiated unity of God or the divine unity in distinction? Recent years have brought numerous studies of traditional teaching and thinking about the Trinity. ${ }^{14}$

The council of Nicaea (325 A. D.) was an epoch in Christian history. The heresy od Sabellius and Paul of Samosata, that refused to recognize the Father as in any personal sense distinct from the Son and the Holy Spirit, had been previously condemned. But Arius, who began with the Sabellian idea that the Trinity is only one of manifestation, change his position and declared that there were three persons in God, but that these three were unequal in glory. ${ }^{15}$ In short, the Son and the Holy Spirit owed their existence to the divine will and, accordingly, were creatures of God.

The Council of Nicaea, in opposition to Arianism and various other theories, adopted the formal statement of the consubstantiality of the Father, the Son and the Holy Spirit, while maintaining the distinction of personality, was seen as the hallmark of orthodoxy. It declared that the Son is "of the same substance" as the Father. The Trinity was affirmed as an article of faith by the Nicene (325/381) and Athanasian creeds (circa 500), which attempted to standardize belief in the face of disagreements on the subject. ${ }^{16}$

The Anathasian Creed, as quoted by Thiessen, expresses the Trinitarian belief. It was written: "We worship one God in the Trinity, and the Trinity in unity; we distinguish among the persons, but we do not divide the substance ... The entire three persons are coeternal and coequal with one another, so that ... we worship complete unity in Trinity and Trinity in unity." ${ }^{\text {"17 }}$

In the fourth century, the Capadocians develop their language of the three co-equal and co-eternal hypostaseis or persons sharing the one divine ousia or essence. After Athanasius and the Capadocians develop

\footnotetext{
${ }^{14}$ Compare with, for instance, C. M. LaCugna, God for Us: The Trinity and Christian Life (San Fransisco: HarperSan Fransisco, 1991); R. William, Arius: Heresy and Tradition (London: Darton, Longman \& Todd, 1987).

${ }^{15}$ Merril F. Unger, Trinity in The New Unger's Dictionary, R. K. Harrison ed. (Chicago: Moody Press, 1988), 1308-1309.

${ }^{16}$ Carol Brooks, The Trinity, available from, http://www.inplainsite.org/html/the_trinity.html, accessed on September, $5^{\text {th }} 2009$.

${ }^{17}$ Henry Clarence Thiessen, Lecture in Systematic Theology (Grand Rapids, Michigan: William B. Eerdmans Publishing Company, 1987), 90.
} 
their Trinitarian, St Augustinus of Hippo (AD 354 - 430), wrote his De Trinitate slowly and arguably in a somewhat less polemical way. He took seventeen years to complete the work, which - one must add - is neither his last nor his only work on the Trinity. ${ }^{18}$

In the Trinitate, which may be his greatest work, Augustine turned his prodigious intellect to the problem of the nature of the Trnity. Augustine emphasizes the unity of God more that the threeness. The three members of the Trinity are separate individuals in the way in which three members of the human race are separate individuals. Each members of the Trinity is in his essence identical with the others or with the divine substance itself. They are distinguished in term of their relations within the Godhead. ${ }^{19}$

${ }^{18}$ Stephen T. Davis eds., The Trinity (New York: Oxford University Press, 1999), 9.

${ }^{19}$ Millard J. Erickson, Christian Theology (Grand Rapids, Michigan: Baker Book House, 1996), 339. 


\section{Chapter II \\ THE EVIDENCE OF THE TRINITY IN THE NEW TESTAMENT}

The doctrine of Trinity is more clearly set forth in the New Testament than in the Old Testament. In the New Testament there is no systematic, point-by-point exposition of the doctrine of the Trinity. Something remarkable happened between the completion of the Old Testament and the first writings of the New. What was vaguely intimated in the Old Testament became a clear, settled doctrine in the New, needing no elaborate definition or defense. ${ }^{20}$

The New Testament clearly says the Trinity that Jesus is God (John 1:1, 14); it says the Father is God (Phil. 1:2); and it says the Holy Spirit is God (Acts 5:3-4). Since the Son speaks to the Father, they are separate persons (John 17). Since the Holy Spirit speaks also (Acts 13:2), He too is a separate person. There can be no question that the New Testament proclaims there is only One God and that He exists in three distinct persons. ${ }^{21}$

The whole mass of the New Testament is evidence for the Trinity. For the New Testament is saturated with evidence of the Deity of Christ and the Divine personality of the Holy Spirit. It shows that the New Testament everywhere insists on the unity of the Godhead; that it constantly recognizes the Father as God, the Son as God and the Spirit as God; and that it cursorily presents these three to us as distinct Persons. It is not necessary, however, to enlarge here on facts so obvious. $^{22}$

\section{A. The Trinity in the Gospel}

The evidence of the Trinity from the Gospels was scattered from the beginning of the Gospel until the end. In the birth narratives, Jesus is conceived by the Holy Spirit (Matt. 1:18, 20; Luke 1:35) and thus "the Son of God" (Luke 1:35) comes to be "Immanuel - God with us" (Matt. 1:30).

\footnotetext{
${ }^{20}$ John M. Frame, The Doctrine of God (Phillipsburg, New Jersey: P\&R Publishing Company, 2002), 638.

${ }^{21}$ Cooper P Abrams III, Understanding the Biblical Doctrine of the Trinity, available from http://www.bible-truth.org/Trinity.html, accessed on September, $7^{\text {th }} 2009$.

${ }^{22}$ Benjamin B. Warfield, The Biblical Doctrine of the Trinity, available from, http://www.lgmarshall.org/ Warfield/warfield_trinity.html, cited on September $5^{\text {th }}$ 2009.
} 
It is undeniable that in Mary's conception the Trinity is involved: the Holy Spirit came upon Mary, the power of God overshadowed her, and the resultant offspring was called the Son of God (Luke 1:35) $)^{23}$

The supernatural appearance at the baptism of Christ is often cited as an explicit revelation of Trinitarian doctrine, given at the very commencement of the Ministry. At that moment, the three persons are present: Jesus, the Spirit descending as a dove (Matt. 3:16; Luke 3:22), and the Father speaking from heaven, "This is my Son, whom I love; with him I am well pleased" (Matt. 3:17; cf. 17:5; Luke 3:22). In the baptismal scene which finds record by all the evangelists at the opening of Jesus ministry (Mt. iii. 16, 17; Mk. i. 10, 11; Lk. iii. 21, 22; Jn. i. 32-34), the three Persons are thrown up to sight in a dramatic picture in which the Deity of each is strongly emphasized.

Besides these passages there are many others in the Gospels which refer to one or other of the Three Persons in particular and clearly express the separate personality and Divinity of each. In the temptation of Jesus (Matt. 4; Luke 4), the name of three persons of the Trinity appear. The temptation is essentially an invitation to Jesus to serve Satan rather that the Father (compare with Adam temptation in the Garden in Genesis 3).

It was written that, the Spirit leads Jesus into wilderness, where Satan tempted him. Satan asked the Son of God to bow down before him and ignore the Father (Matt 4:4, 7, 10). Jesus then returns to Galilee, victoriously, "in the power of the Spirit" (Luke 4:14), he casts out devils by the Spirit of God (Matt. 12:28) to show that the kingdom of God (the Father) has come.

The testimony of John the apostle in the gospel of John is yet more explicit than that of the Synoptists. He expressly asserts that the very purpose of his Gospel is to establish the Divinity of Jesus Christ (John 20:31). In the prologue he identifies Him with the Word, the onlybegotten of the Father, Who from all eternity exists with God, Who is God (John 1:1-18).

The richest Trinitarian teaching in the Gospel is in the Johannine discourses preceding Jesus' atoning death. Here Jesus expresses eternal intimacy with the Father (compare with John 17:5, 10-11, 22, 26), and promises to send upon the church the Holy Spirit from the Father, and to come to the "Father's house" in the Spirit (Compare with John 14:2-6; 16-

${ }^{23}$ Paul Enns, The Moody Handbook of Theology, (Chicago: Moody Press, 1989), 202. 
18, 26; 15:26; 16:13-15; 20:21-22). Millard J. Erickson mentioned as he quoted George Henry observation as follows:

It is in the fourth Gospel that the strongest evidence of a coequal Trinity is to be found. The threefold formula appears again and again: 1:33-34; 14:16, 26; 16:13-15; 20:21-22 (cf. 1 John 4:2, 13-14). The inter-dynamics among the three persons come through repeatedly. The Son is sent by the Father (14:24) and comes forth from him (16:28). The Spirit is given by the Father (14:16), sent from the Father (14:26); and proceeds from the Father (15:26). Yet the Son is closely involved in the coming of the Spirit: he prays for his coming (14:16); the Father sends the Spirit in the Son's name (14:26); the Son will send the Spirit from the Father (15:26); the Son must go away so that he can send the Spirit (16:7). The Spirit's ministry is understood as a continuation and elaboration of that of the Son. He will bring to remembrance what the Son has said (14:26); he will bear witness to the Son (15:26); he will declare what he hears from the Son, thus glorying the Son (16:13-14). ${ }^{24}$

The evidence from the Gospels culminates in the baptismal commission of Matthew 28:20. After His resurrection, He revealed the doctrine in explicit terms, bidding them "go and teach all nations, baptizing them in the name of the Father, and of the Son, and of the Holy Ghost" (Matthew 28:18). Kevin Knight, one of Catholic scholar summarized as follows:

The force of this passage is decisive. That "the Father" and "the Son" are distinct Persons follows from the terms themselves, which are mutually exclusive. The mention of the Holy Spirit in the same series, the names being connected one with the other by the conjunctions "and ... and" is evidence that we have here a Third Person co-ordinate with the Father and the Son, and excludes altogether the supposition that the Apostles understood the Holy Spirit not as a distinct Person, but as God viewed in His action on creatures. $^{25}$

By quoting George Joyce, "The Blessed Trinity" in the Catholic Encyclopedia, Kevin Knight continued his explanation.

\footnotetext{
${ }^{24}$ Millard J. Erickson, Christian Theology (Grand Rapids, Michigan: Baker Book House, 1996), 331-332.

${ }^{25}$ Kevin Knight ed., The Blessed Trinity, available from, http://www.newadvent.org/cathen/15047a.htm, accessed on September $5^{\text {th }} 2009$.
} 
The phrase "in the name" (eis to onoma) affirms alike the Godhead of the Persons and their unity of nature. Among the Jews and in the Apostolic Church the Divine name was representative of God. He who had a right to use it was invested with vast authority: for he wielded the supernatural powers of Him whose name he employed. It is incredible that the phrase "in the name" should be

here employed, were not all the Persons mentioned equally Divine. Moreover, the use of the singular, "name," and not the plural, shows that these Three Persons are that One Omnipotent God in whom the Apostles believed. ${ }^{26}$

One name is here applied to three divine beings, coordinate with each other. It seems clear that the equality as well as the unity of three persons is intended.

\section{B. The Trinity in Book of Acts}

The Book of Acts also contains or talks about the Trinity. The outpouring of the Spirit at the Pentecost brought the personality of the Holy Spirit into greater prominence and at the same time shed light anew from the Spirit upon the Son. Peter, in explaining the phenomenon of Pentecost, represents it as the activity of the Trinity. ${ }^{27}$

Peter, by the power of the Holy Spirit, explains: "God has raised this Jesus to life, and we are all witnesses of the fact. Exalted to the right hand of God, he has received from the Father the promised Holy Spirit and has poured out what you now see and hear (Acts 2: 32-33). This declaration implicitly pronounces that the church of Pentecost was founded on the doctrine of the Trinity.

Furthermore, Peter urges the people to "repent and be baptized, every one of you, in the name of Jesus Christ for the forgiveness of your sins. And you will receive the gift of the Holy Spirit. The promise is for you and for your children and for all who are far - for all whom the Lord our God will call." (Acts 2:38-39).

The Father offers the Holy Spirit to all who embrace the Son in faith. Such as, for instance, "Stephen, a man full of faith and of the Holy Spirit" (Acts 6:5), and Paul (Acts 9:17-19). It was written in Acts 7:55,

\footnotetext{
${ }^{26}$ Kevin Knight ed., The Blessed Trinity, available from, http://www.newadvent.org/cathen/15047a.htm, accessed on September $5^{\text {th }} 2009$.

${ }^{27}$ J. D. Douglas eds., New Bible Dictionary, $2^{\text {nd }}$ edition, s. v. Trinity (Wheaton, Illinois: Tyndale House Publisher, Inc., 1990), 1222.
} 
"But Stephen, full of the Holy Spirit, looked up to heaven and saw the glory of God, and Jesus standing at the right hand of God."

\section{The Trinity in Pauline Letters}

The evidence of the Trinity in Pauline letters can be seen in numerous passages of his writings. In numerous passages scattered through Paul's Epistles, from the earliest of them to the latest, all three Persons, God the Father, the Lord Jesus Christ and the Holy Spirit, are brought together, in the most incidental manner, as co-sources of all the saving blessings which come to believers in Christ. ${ }^{28}$

For instance, such as, in 1 Corinthians 12:4-6, Paul presents the abounding spiritual gifts with which the church was blessed in a threefold aspect, and connects these aspects with the three Divine Persons. "There are different kinds of gifts, but the same Spirit. There are different kinds of service, but the same Lord. There are different kinds of working, but the same God, who works all of them in all men." Benjamin B. Warfield commented,

It may be thought that there is a measure of what might almost be called artificiality in assigning the endowments of the church, as they are graces to the Spirit, as they are services to Christ, and as they are energizings to God. But thus there is only the more strikingly revealed the underlying Trinitarian conception as dominating the structure of the clauses: Paul clearly so writes, not because "gifts," "workings," "operations" stand out in his thought as greatly diverse things, but because God, the Lord, and the Spirit lie in the back of his mind constantly suggesting a threefold causality behind every manifestation of grace. The Trinity is alluded to rather than asserted; but it is so alluded to as to show that it constitutes the determining basis of all Paul's thought of the God of redemption. ${ }^{29}$

Another instruction regarding of the Trinity was found in the apostolic benediction: "May the grace of the Lord Jesus Christ, and the love of God, and the fellowship of the Holy Spirit be with you all." ${ }^{30}$ Here the

${ }^{28}$ Comparing with: 1 Thess. 1: 2-5; 2 Thess. 2:13, 14; Tit. 3:4-6; 2 Tim. 1:3, 13, 14; Eph. 2:18; 3:2-5, 14, 17; 4-6; 18-20.

${ }^{29}$ Benjamin B. Warfield, The Biblical Doctrine of the Trinity, available from, http://www.lgmarshall.org/Warfield/warfield_trinity.html, cited on September $5^{\text {th }}$ 2009.

302 Corinthians 13:14 NIV 
three highest redemptive blessings are brought together, and attached distributively to the three Persons of the Triune God. The construction shows that the Apostle is speaking of three distinct Persons. Moreover, since the names God and Holy Spirit are alike Divine names, it follows that Jesus Christ is also regarded as a Divine Person.

It is not only sums up the apostolic teaching, but interprets the deeper meaning of the Trinity in Christian experience; the saving grace of the Son giving access to the love of the Father and to the communion of the Spirit. ${ }^{31}$

In this apostolic benediction, Paul simply thinking of the Divine source of these great blessings; but he habitually thinks of this Divine source of redemptive blessings after a trinal fashion. He therefore does not say, as he might just as well have said, "The grace and love and communion of God be with you all," but "The grace of the Lord Jesus Christ, and the love of God, and the communion of the Holy Spirit, be with you all." Thus he bears, almost unconsciously but most richly, witness to the trinal composition of the Godhead as conceived by Him.

This is only a sampling of other similar passages in Pauline letters. Among others are the following: Romans 14:17-18; 15:16; 1 Corinthians 2:2-5; 6:11; 12:4-6; 2 Corinthians 1:21-22; Galatians 4:6; Ephesians 2:18-22; 3:14-19; Ephesians 4:4-6; Colossians 1:6-8; 1Thessalonians 1:3-5; 2 Thessalonians 2:13-14; Titus 3:4-6. The reader is encouraged to read each of these passages and note how God (Father), Son (Jesus Christ) and the Holy Spirit are brought together as instruments of our salvation. ${ }^{32}$

\section{The Trinity in the Letter of Peter}

The phenomena of Paul's Epistles are repeated in the other writings of the New Testament. In these other writings also it is everywhere assumed that the redemptive activities of God rest on a threefold source in God the Father, the Lord Jesus Christ, and the Holy Spirit; and these three Persons repeatedly come forward together in the expressions of Christian hope or the aspirations of Christian devotion. ${ }^{33}$

\footnotetext{
${ }^{31}$ J. D. Douglas eds., New Bible Dictionary, $2^{\text {nd }}$ edition, s. v. Trinity (Wheaton, Illinois: Tyndale House Publisher, Inc., 1990), 1222.

${ }^{32}$ Paul Kroll, Is the Trinity in the Bible? Available from

http://www.wcg.org/lit/God/trinitybible.htm, accessed on September $7^{\text {th }} 2009$.

${ }^{33}$ For instance we can see such as in Heb. 2:3, 4; 4:4-6; 10:29-31; 1 Pet. 1:2; 2:312; 4:13-19; I Jn. 5:4-8; Jude 20, 21; Rev.1:4-6.
} 
In the first letter of Peter was written: "To God's elect, ... who have been chosen according to the foreknowledge of God the Father, through the sanctifying work of the Spirit, for obedience to Jesus Christ and sprinkling by his blood. ${ }^{34}$ Peter traces salvation to the same tribunal source: 'destined by God the Father and sanctified by the Holy Spirit, for obedience to Jesus Christ' (1 Pet. 1:2). ${ }^{35}$ Peter write out of a fixed Trinitarian consciousness and bear his testimony to the universal understanding current in apostolical circles.

Everywhere and by all it was fully understood that the one God whom Christians worshipped and from whom alone they expected redemption and all that redemption brought with it, included within His undiminished unity the three: God the Father, the Lord Jesus Christ, and the Holy Spirit, whose activities relatively to one another are conceived as distinctly personal.

${ }^{34} 1$ Peter 1:1-2, NIV.

${ }^{35}$ J. D. Douglas eds., New Bible Dictionary, $2^{\text {nd }}$ edition, s. v. Trinity (Wheaton, Illinois: Tyndale House Publisher, Inc., 1990), 1222. 


\section{Chapter III CONCLUSION}

The doctrine of the Trinity has been a divisive issue throughout the entire history of the Christian church. While the core aspects of the Trinity are clearly presented in God's Word, some of the side issues are not as explicitly clear. The Father is God, the Son is God, and the Holy Spirit is God-but there is only one God. That is the biblical doctrine of the Trinity. Beyond that, the issues are, to a certain extent, debatable and non-essential. Rather than attempting to fully define the Trinity with our finite human minds, we would be better served by focusing on the fact of God's greatness and His infinitely higher nature.

James R. White, a Christian apologist, says in his book The Forgotten Trinity: "The Trinity is a doctrine not revealed merely in words but instead in the very action of the Triune God in redemption itself! We know who God is by what He has done in bringing us to himself!!"36

Although the doctrine of the Trinity is not expressly asserted, the Scripture, particularly the New Testament, contain so many suggestions of the deity and unity of the three persons that we can understand why the church formulated the doctrine, and conclude that they were right in doing.

From the Second Century to our present age many people have found the biblical doctrine of the Trinity hard to understand. Someone has said of this doctrine: "Try to explain it, and you'll lose your mind; but try to deny it, you'll lose your soul.

\footnotetext{
${ }^{36}$ Paul Kroll, Is the Trinity in the Bible? Available from, http://www.wcg.org/lit/God/trinitybible.htm, accessed on September, $7^{\text {th }} 2009$.
} 


\section{BIBLIOGRAPHY}

\section{Books}

Berkhof, Louis. Systematic Theology. Grand Rapids: William B Eerdmans, 1941.

Davis, Stephen T. eds. The Trinity. New York: Oxford University Press, 1999.

Enns, Paul. The Moody Handbook of Theology. Chicago: Moody Press, 1989.

Erickson, Millard J. Christian Theology. Grand Rapids, Michigan: Baker Book House, 1996.

Frame, John M. The Doctrine of God. Phillipsburg, New Jersey: P\&R Publishing Company, 2002.

Oden, Thomas C. The Living God. New York: Harper Collins Publisher, 1987.

Thiessen, Henry Clarence. Lecture in Systematic Theology. Grand Rapids, Michigan: William B. Eerdmans Publishing Company, 1987.

\section{Dictionaries}

Douglas, J. D. eds. New Bible Dictionary, $2^{\text {nd }}$ edition. Wheaton, Illinois: Tyndale House Publisher, Inc., 1990.

Unger, Merril F. The New Unger's Dictionary. Chicago: Moody Press, 1988.

\section{Websites}

Abrams III, Cooper P. Understanding the Biblical Doctrine of the Trinity, available from http://www.bible-truth.org/Trinity.html.

Brooks, Carol. The Trinity, available from, http://www.inplainsite.org/html/the_trinity.html.

Knight, Kevin, ed. The Blessed Trinity, available from, http://www.newadvent.org/cathen/15047a.htm

Kroll Paul. Is the Trinity in the Bible? Available from, http://www.wcg.org/lit/God/trinitybible.htm.

Oakes, John. The Origin of the Trinity, available from, http://www.evidenceforchristianity.org/index.php?option=com_custom_ content\&task=view\&id=4999

The symbol for the Trinity, available from, http://www.gotquestions.org/TrinityBible.html.

Warfield, Benjamin B. The Biblical Doctrine of the Trinity, available from, http://www.lgmarshall.org/Warfield/warfield_trinity.html. Watchtower Hypocrisy: "The word Trinity is not found in the Bible?" Available from, http://www.bible.ca/trinity/trinity-word-not-inbible.htm, 